\title{
Internet resources for music
}

\author{
By Richard AmRhein
}

\section{Roll over, Beethoven-bere come Yaboo's Music and other sites}

五 xploring the Internet for music resources presents a special challenge for the user. Music is a topic of broad popular appeal and one of intense research for all types of people, from music hobbyist to musicologist. Consequently, the Internet is the source of a plethora of music information, from details of the works of J. S. Bach (http://www.tile.net/tile/bach/ index.html) to the latest accordion jokes (http: //www.mit.edia:8001/people/jcb/otherinstrument-jokes.html\#accordion).

This article is simply an attempt to introduce the user to some music resources available on the Internet. It is not comprehensive and is certainly not exhaustive. I have not included most popular and rock and roll sites because the sheer volume of resources in these areas would make it impossible to include anything else. Persons interested in these resources can easily find them through several of the gateway systems listed below.

Perhaps the most difficult part of searching the Internet for music resources is that you find so many interesting paths to take along the way that it is easy to forget what you were searching for to begin with. The "Other Interesting Sites" listed at the end of this article were chosen to illustrate the variety of types of resources available. Beginners may wish to start there.

\section{Gateway systems: Major listings and indexes of music sites}

- The Ever Expanding Web Music Listing. An enormous listing of music sites organized into about a dozen categories. Access. http://www.columbia.edu/ hauben/music- index.html, mirrored at http://woof.music. columbia.edu/ hauben/music-index.html.

- Indiana University Music Library. One of the finest, most well-organized collections of music sites available. Access: http:/ www. music.indiana.edu/misc/music_resources.html.

- Internet Underground Music Archive (IUMA). Home to free digitized music from all sorts of bands online. It provides a venue for artists to have global exposure via the World Wide Web. Access: http://www.iuma.com.

- Library of Congress. Through its Global Electronic Library in MARVEL, a wide variety of music resources are available. Access: gopher://marvel.loc.gov/11/global/arts/music.

- Library of Musical Links. Provides thousands of links to music-related information-Web pages, gopher and ftp sites, newsgroups, and mailing lists. Access: http:/, www-scf.usc.edu/ jrush/music/index.html.

- Mammoth Music Meta-List. Provides a broad overview of music resources available. It offers a What's New link so users they can contribute. Access: http://pathfinder.com/@@ cHnW@CFcIAIAQBBG/vibe/mmm/music.html.

- Web Wide World of Music. Includes what it calls the Ultimate Chat List, an application that helps find chat sessions online, and the Ultimate Band List, an interactive guide to thousands of band Web pages, music and lyr ics servers. Access: http://american recordings. $\mathrm{com} / \mathrm{WWWOM}$

- Yahoo's Music. Yahoo! is a hierarchical subject-oriented guide for the World Wide Web and Internet. It is well organized and updated continuously. Access: http://www yahoo. $\mathrm{com} /$ Entertainment/Music.

\section{Discussion lists and e-journals}

- List of Musical Lists. A directory of all known music-related mailing lists. These mail- 
ing lists are generally for the discussion of a specific music artist or group, or music topic via e-mail. The first two parts of the list covers hundreds of popular music artists' discussion lists. Access: http://server.berkeley.edu/ ayukawa/lomml.html.

- Accordions. Focuses on playing and repairing piano and button accordions, concertinas, and all other free reeds but harmonicas.Subscribe: accordion-request@cs.cmu.edu.

- Bagpipes. Any topic related to bagpipes, most generally defined as any instrument where air is forced manually from a bellows or bag through drones and/or over reeds. Subscribe: bagpipe-request@cs.dartmouth.edu. Gatewayed to the Usenet newsgroup rec.music.makers. bagpipe. Archives: gopher://cs.dartmouth.edu/ 11/pub/bagpipes.

\section{- Bluegrass \& Old-time Country Music}

(BGRASS-L). Devoted to bluegrass and old-time country music. A daily digest option is available and suggested for this active group. Subscribe: listserv@ukcc.uky.edu.

- Blues Music (Blues-L). For everyone who can't get enough of the blues. Subscribe: listserv@brownvm.brown.edu.

- Brass. A discussion group for people interested in brass musical performance and related topics, especially small musical ensembles of all kinds. Subscribe: brass-request@geomag. gly.fsu.edu.

- Choralist. A communication mechanism for the exchange of information and ideas among practicing choral conductors. Open to anyone, but is specifically oriented toward the choral conducting professional. Subscribe: listproc@lists.colorado.edu.

- Classical Music (Classical). Discusses music, musicians, composers, composition, instruments, performance, music history, recordings and all topics even remotely related to classical music from all periods. Subscribe: classical-request@webcom.com.

- DOUBLEREED-L. Discussion of all matters relating to double-reed instruments. Subscribe: listserv@acc.wuacc.edu.

- Drum. For discussion of anything related to drums and percussion. Subscribe: drumrequest@brandx.Rain.COM. For digest version: drum-digest-request@brandx.Rain.COM.

- Ethnomusicology Research Digest (ETHMUS-L). News, discussion, and queries for anyone with a professional interest in ethnomusicology. Subscribe: LISTSERV@UMDD. UMD.EDU.
- Film Music (FILMUS-L). Discussion of dramatic music for film and television. Subscribe: listserv@iubvm.ucs.indiana.edu.

- Flute (FLUTE-M). Discussion of the flute, flute playing, players, and flute music. Subscribe: flute-m-request@unixg.ubc.ca.

- Folk Music, New American (FOLK MUSIC). A moderated discussion list dealing with the music of the recent wave of American singer/songwriters. List traffic consists of tour schedules, reviews, album release info, and other information on artists. Subscribe: listserv@nysern et.org.

- Harpsichords (HPSCHD-L). Devoted to discussion of early stringed keyboard instruments: harpsichords, clavichords, fortepianos, virginals, and all similar instruments except the modern piano. Subscribe: listserv@albany.edu.

- French Horn (HORN). The International Horn Society maillist provides a forum for electronic conversation about all things relating to the French horn. Subscribe: majordomo @spock.nlu.edu.

- Impulse Music Journal (IMPULSE) A journal of music news, reviews, information, and opinion. Published monthly. Subscribe: impulse@dsigroup.com. Also available at gopher://enews.com and telnet:/enews.com, login: enews.

- Irish Traditional Music (IRTRAD-L). Discusses all aspects of Irish traditional music, new and old. Subscribe: listserv@irlearn.ucd.ie.

- Lute. For lute players and researchers of lute music. Subscribe: lute-request@cs. dartmouth.edu.

- Music Library Association Mailing List (MLA-L). For various activities of MLA that can benefit by wide-scale distribution, and for reference inquiries and other topics of interest to the music library community. Subscribe: listserv@iubvm.ucs.indiana.edu.

- Music-Research. Provides a means of bringing together musicologists, music analysts, computer scientists, and others working on applications of computers in music research. Subscribe: Music-Research-Request@prg.oxford. ac.uk. Subscription requests from outside the U.K.: contact the U.S. redistributor: music-research-request@cattell.upenn.psych.edu.

- Music Theory Online (MTO). A refereed e-journal covering any topics of interest to the music theory community. Subscribe: http: //boethius.music.ucsb.edu/mto mtohome.html.

- Musicals. Intended for the general discussion of musical theater, in whatever form it 
may take. This is a gateway of the newsgroup recarts theatre.musicals. Subscribe: majordono @world.std.com.

- Orchestralist. Serves the professional needs of conductors, composers, managers, and others in the orchestral business. Subscribe listproc@hubcap.clemson.edu.

- Pipe Organs and Related Topics (PIPORG-L). Discusses musical, technical, and historical aspects of organs of all kinds-classical. theater, electronic, reed, tracker, electropneumatic, etc. Subscribe: listserv@ albany.edu.

- Sacred Harp/Shape-Note Singing (fasola). Dedicated to discussion and announcements of Sacred Harp singing and related traditions. Subscribe: majordomo@tahiti. umlic.umn.edu.

- Trombone (Trombone-L). Discusses all aspects of trombone playing and trombonists. Sibscribe: listproc@showme.missouri.edu. URL: http://www.missouri.edu/ cceric/index.html.

- Trumpet. Discusses all aspects of trumpet playing and trumpeters. Subscribe listserv@acad1.dana.edu. For digest version: subscribe trumpet-digest.

- Tuba and Euphonium (TUBAEUPH). Discusses tuba, euphonium, and baritone playing and players. Subscribe: listserv@cmsvmb. missouri.edu.

- Vocalist (Classical Singing Mailing List). Discussion for students, teachers, and others interested in classical singing. Subscribe: majordomo@lists.oulu.fi. URL: http://ists. oulu. $\mathrm{fi} /$ lists/vocalist/

\section{Newsgroups}

There are hundreds of newsgroups devoted to the discussion of music. The best way to approach newsgroups for music is to understand the hierarchical structure within which most musical discussion groups fall. The two main hierarchies used for music are alt.* and rec.* Within those hierarchies further division can be made and, in many cases, the subject of the newsgroup becomes evident

alt.music.*: alt music.african, alt.music.bigband, alt.music.canada, alt.music.hawaiian, alt.music.jewish, alt.music midi, alt.music.misc, alt.music polkas, alt music.rockabilly, alt. music.sondheim, and countless rock groups.

rec.music.": rec.music afro-latin, rec. music beatles, recmusic bluenote, rec. music.celtic, rec.music.classical, rec.music. collecting, rec.music.compose, rec.music. country.western, rec.music.early, rec.music.folk, rec.music.indian.classical, rec.music.info, rec.music.movies, rec.music.newage, rec. music.opera, rec.music ragtime.

Music newsgroups with the word makers in the title are for people who play the instrument described-i.e., rec.music.makers. bagpipe, rec.music.makers.bowed-strings, rec.music makers builders, rec.music makers. fiench-horn.

Other alt.* subdivisions inclucle alt.guitar, alt.banjo, alt.rap, alt.fan, alt.radio, and alt.rockn-roll. One can also explore rec.arts. ${ }^{*}$ for broader discussions and fan." for the numerous fan clubs out there.

\section{Artists' representatives}

- ASCAP (American Society of Composers, Authors, and Publishers). Representing songwriters, composers, and music publishers in all areas of music, ASCAP distributes public performance royalties to its affiliates. ASCAP BBS allows music professionals and the public to exchange information. Its ASCAP Clearance Express Database makes the multimillion-title ASCAP repertory searchable by title, composer, publisher, and performer information. Access: http:/ascap.com.

- BMI (Broadcast Music, Inc.). Representing songwriters, composers, and music publishers in all areas of music, BMI distributes royalties to its affiliates for public performance. With the assistance and support of the U.S. Copyright Office of the Library of Congress (http://cweb.loc.gov/copyright), BMI also provides access to forms that songwriters, composers, and publishers may need in the ordinary course of their business. Access: http: bmi.com.

- Harry Fox Agency. Provides an information source, clearinghouse, and monitoring service for licensing musical copyrights. Represents more than 13,000 American music publishers and licenses a large percentage of the uses of music in the United States on records, tapes, CDs, and imported phonorecords. It also licenses music on a worldwide basis on behalf of its publisher principals for use in films, commercials, television programs, and all other types of audiovisual media. Access: http:// www.nmpa.org/hfa.html.

\section{Music education}

- Brent Hugh's Music Instruction Software Page. Contains pointers to programs of 
interest to music teachers. The main focus is programs that will help students master the basics of music. Access: http://cctr.umkc.edu/ userx/bhugh/musici.html.

- Music Educators' Homepage. This homepage contains music curriculum materials and links to other useful sites that may be of benefit to the classroom music teacher. $A C$ cess: http://athena.athenet.net/ wslow/ inclex.html.

\section{Song lyrics}

- Digital Tradition Folk Song Database. A database containing the words and music to thousands of folk songs. Access: http:/ web2.xerox.com/digitrad.

- The Lyrics Page. This site mirrors ftp.uwp.edu's enormous lyrics archive. Users can submit additions to the archive. Access: http://vivatin.pc.cc.cmu.edu/lyrics.htmal.

- Russian Club Songs Home Page. Transliterated lyrics to Russián songs. Access: http:/ anxiety-closet.mit.eclu:8001/activities/russiánclub/cátálog.html.

\section{Other interesting sites}

- American Music Center. Maintains a circulating collection of over 55,000 scores and recordings and provictes assistance to composers and performing groups. Access: http:// www.amc.net/amc.

- J. S. Bach Home Page. Provicles extensive information about his works and recordings as well as photographs and biographical information. Access: http://www tile.net/tile/ bach/index.html. Also provides access to the J. S. Bach Archive and Bibliography. Access: http://www.let.rug.nl/Linguistics/diversen/ bach/intro.htmal.

- Beethoven Bibliography Database. A research project of the Ira F. Brilliant Center for Beethoven Studies at San Jose State University. Inclexes books and articles about Ludwig van Beethoven and first and early editions of his scores. Access: telnet://ib, then press D@SJSLILIB1.SJSU.EDU :23 (type URL exactly as shown). Choose I)> Connect to another clatabase.

- Canadian Music Exchange. A comprehensive guide to the music of Canadians and the industry that surrounds it. Includes the Music Industry Contact List which provicles access to record labels, producers, recording studios, promoters and booking agencies, etc. Access: http: www.io.org/ cme.
- Drums and Percussion Page. Includes announcements, the groove archive (drumset and hand drums), clrummers and percussionists on the Net, clrum- and percussion-related organizations, FAQs, an encyclopedia, method books, companies, etc., not to mention drummer jokes. Access: http://www.cse.ogi.edu/ Drum.

- Gregorian Chant Tutorial. From the University of Vienna, it provicles basic information in English about Gregorian chant. $A C$ cess: gopher://osiris.wu-wien.ac.at:7121/11/ pub/earlym-l/gregorian.chants.

- On-line Guitar Archive (OLGA). An archive of thousands of files containing words and music (in chord and tab format) specifically written for use by guitar players. Access: ftp://ftp.nevada.edu/pub/guitar, littp:// www.guitar.net/olga.html, ftp://mirrors.aol com/pul)/guitar.

- Renaissance Consort. Sound demonstrations of Renatissance instruments. Access: http://www.hike.te.chiba-u.alc.jp/cons1.

- Rock and Roll Hall of Fame. Frequently adds stories about the Rock and Roll Hall of Fame and Museum. Access: http://www. rockhall.com.

- Thesaurus Musicarum Latinarum. Downloadable texts of treatises on music theory written during the Midclle Ages and the early Renaissance. Access: gopher://iubvm.ucs. indiana.eclu/11/tml.

- Vatican Exhibit-Music Section. "From Gregorian Chant to Opera's Origins" is one of a nine-part online exhibit from the Library of Congress entitled "Rome Reborn: The Vatican Library and Renaissance Culture." Access: http: /141.142.3.130/SDG/Experimental/vatican. exhibit/exhibit/e-music/Music.html

- WAIS Databases in Music. A single search engine for any or all of the following WAIS databases you want to search: BGRASSL, bluegrass mailing list archives; MuTeX, mailing list archives; Omni-Cultural-Academic-Resource, colbase, midi, music-surveys, rec music.early, Sheet_Music_Index, earlym-1, london-free-press-regional-index. Access: http: /www.ub2.lu.se/auto_new/auto_54.html.

- Welcome to the World of Classical Music. This is an introcluction to the appreciation of classical music. Access: http: classicalmus.com.

- WNUR-FM Jazzweb. A user-built project by WNUR-FM at Northwestern Iniversity. Access: http://www.acns.nwuledu/jazz. 


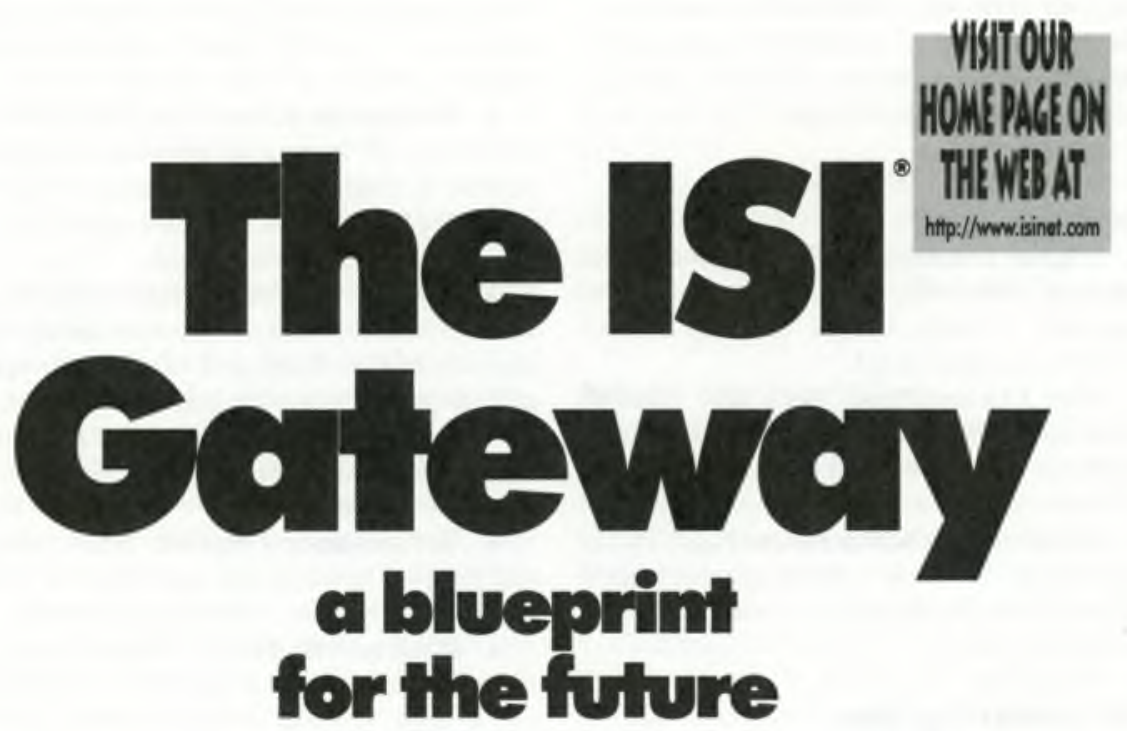

Rapid and radical changes are sweeping the information industry. Meeting the resulting needs and demands of the worldwide research community will require insight from today - and foresight for tomorrow. In fact, it will require a plan. Not just talk. But a real blueprint for the future.

IST's advanced data-capture tochnology is a case in point. We're working in close partnership with the publishing and library communities in an important, exciting venture: to use that technology to build a full-text database that eventually will allow for instantaneous, electronic deliv: ery of any research document to any workstation in the world.
Or consider our aggresxive product development program. It begins with exhaustive market research: what do you, the customer, need? What format? What breadth of coverage? It ends with both new and enhanced products that make your job easier. Current Contents ${ }^{\infty}$ on CDROM, custom profiles delivered via Internet, proceedings indexes on CD-ROM. the Index Chemicus ${ }^{*}$ Database, to name but a few.

The blueprint doesn't end there. Other significant initiatives include a selective expansion of our editorial coverage, to provide continuing access to the most relevant, high-impact literature in all schol-

\section{is:}

Institute for Scientific Information, Inc. arly disciplines. Creating new software interfaces for consistent, user-friendly access to our entire electronic product line. And developing pilot projects with new technology partnen to keep pace with a shifting information landscape.

And the ISI Gateway itself? It will provide the link between information seekers and the sources of scholarly research. Across all publishing channels and all disciplines, in whatever format the customer prefers.

The ISI Gateway: Linking the International Research Community

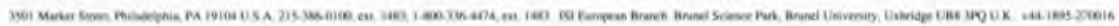

